\title{
The Relationship between Osteoarthritis and Osteoporosis in Patients with Primary Generalized Osteoarthritis
}

\author{
Primer Jeneralize Osteoartritli Hastalarda Osteoartrit ve Osteoporoz Arasındaki İlişki
}

\author{
Aigul ZHOLDOSHOVA, Peyman YALÇIN \\ Department of Physical Medicine and Rehabilitation, Medical Faculty of Ankara University, Ankara, Turkey
}

\begin{abstract}
Objectives: This study aims to examine the relationship between primary generalized osteoarthritis $(\mathrm{OA})$ and bone mineral density (BMD) and to investigate whether $\mathrm{OA}$ patients have a higher BMD value than healthy individuals.

Patients and methods: The study population consisted of 80 postmenopausal female patients (mean age $58.95 \pm 4.63$ years) who suffered from hand OA with Heberden's nodes, while the control group consisted of 80 postmenopausal female patients (mean age $57.62 \pm 5.39$ ) without symptomatic OA and Heberden's nodes. The patients were age-matched. Blood biochemistry, thyroid function tests and bone turnover markers (serum calcium, phosphorus, alkaline phosphatase, osteocalcin, and urine deoxypyridinoline) and 25-hydroxyvitamin D3 [25(OH)D3] levels of the participants were measured. A comparison was made between the two groups with regard to BMD levels, lateral thoracolumbar X-rays, and anteroposterior radiographs of the pelvis, knees, and hands. The evaluation of the radiographs was based on the Kellgren-Lawrence scale. The lumbar and femoral BMD levels in both groups were measured in $\mathrm{g} / \mathrm{cm}^{2}$ with dual-energy X-ray absorptiometry.
\end{abstract}

Results: The 25(OH)D3 value of the OA group was significantly higher than the control group, indicating a statistically significant difference. The lumbar spine BMD levels were statistically higher in the control group compared with the OA group, however, there were no significant differences in the hip BMD values and lumbar spine $\mathrm{T}$ scores between the groups.

Conclusion: Our study results suggest that primary generalized $O A$ is not protective against osteoporosis.

Key words: Bone mineral density; osteoarthritis; osteoporosis.
Amaç: Bu çalışmada primer jeneralize osteoartrit (OA) ile kemik mineral yoğunluğu (KMY) arasındaki ilişki incelendi ve bu hastaların sağlıklı kişilere kıyasla, daha fazla KMY'ye sahip olup olmadıkları araştıııld.

Hastalar ve yöntemler: Heberden nodülleri olan el OA'lı postmenopozal 80 kadın hasta (ort. yaş $58.95 \pm 4.63$ yıl) $\mathrm{OA}$ grubu, Heberden nodülleri ve semptomatik OA'sı olmayan, 80 hasta (ort. yaş $57.62 \pm 5.39$ ) kontrol grubu olarak çalışmaya alındı. Hastalar yaş uyumlu idi. Katılımçların kan biyokimyası, tiroid fonksiyon testleri ve kemik döngü belirteçleri (serum kalsiyum, fosfor, alkalen fosfataz, osteokalsin ve idrarda deoksipridinolin) ve 25-hidroksivitamin D3 [25(OH)D3] düzeylerine bakıldı. Kemik mineral yoğunluğu değerleri, yan torakolomber grafileri, pelvis, diz ve el ön-arka radyografileri iki grup arasında karşılaştırmalı olarak değerlendirildi. Grafilerin değerlendirilmesi Kellgren-Lawrence skalasına göre yapıldı. Her iki grubun lomber ve femur KMY ölçümleri çift $X$ ışınlı absorpsiyometri cihazı ile $\mathrm{gr} / \mathrm{cm}^{2}$ olarak ölçüldü.

Bulgular: Osteoartrit grubunda 25(OH)D3 değeri OA grubunda kontrol grubuna göre yüksek bulundu ve bu fark istatistiksel olarak anlamlıydı. Lomber vertebral KMY düzeyi kontrol grubunda, OA grubuna kıyasla, istatistiksel olarak yüksekti, ancak kalça KMY ve lomber vertebral T skoru değerlerinde gruplar arasında anlamlı fark saptanmadı.

Sonuç: Çalışma bulgularımız, primer jeneralize osteoartritin osteoporoza karşı koruyucu olmadığını göstermektedir.

Anahtar sözcükler: Kemik mineral yoğunluğu; osteoartrit; osteoporoz. 
Two of the primary health issues that the elderly population deals with today are osteoarthritis (OA) and osteoporosis (OP). Osteoarthritis is a slowly progressive, chronic, degenerative disease that is characterized by articular cartilage loss and periarticular bone remodeling. The prevalence of $\mathrm{OA}$ is increasing due to prolonged survival, widespread obesity, and increased trauma (i.e., sports injuries). ${ }^{[1,2]}$ Osteoporosis is a systemic skeletal disease which is characterized by decreased bone mineral density (BMD) and increased fracture risk. It increases bone fragility by reducing bone strength and causing fractures with minimal trauma during daily living activities.

The coexistence of OA and OP in a person is rare, but there are case series concerning patients that were operated for a hip fracture related to OP who did have primary hip OA. Furthermore, the bone mass in patients operated on for hip OA was higher than for patients without OA. Based on these studies, OA has been suggested to be protective against OP ${ }^{[3]}$ However, the relationship between the two diseases is still not fully understood. Study results vary according to the region of the bone mass measurement, measurement technique, and OA joint involvement (differences in the rate of bone regeneration of weight-bearing and non-weight-bearing joints, etc.). In studies based on bone densitometry and radiological evaluation, the BMD was significantly higher in patients with knee and hip OA containing osteophytes. ${ }^{[4.5]}$ Zhang et al. ${ }^{[6]}$ showed that women with high BMD have an increased risk of radiographic knee OA. However, in other studies that focused on women with large joint OA, although the bone mass was above average, the risk of bone fracture risk did not decrease. ${ }^{[7]}$ Hence, the presence of OA does not reduce the risk of fracture. In addition, researchers found that in postmenopausal women with spinal OA, the risk of vertebral fractures was not decreased in spite of the patients having high BMD. In these cases, it was determined that the narrowing in the disc space contributed to the increased risk of vertebral fracture. ${ }^{[8]}$

The relationship between $\mathrm{OA}$ and $\mathrm{OP}$ varies according to whether the patient has primary generalized $\mathrm{OA}$ or localized $\mathrm{OA}$, and studies exist which show that OA in hand joints and OP can be found together. ${ }^{\left[{ }^{[]}\right.}$

The purpose of this study was to examine the relationship between OA and OP in postmenopausal women with hand OA characterized by Heberden's nodes and to investigate whether these patients have higher BMD values in the lumbar spine and femur than those without OA.

\section{PATIENTS AND METHODS}

This study included a total of 160 age-matched patients. The OA group was composed of 80 postmenopausal female patients (mean age $58.95 \pm 4.63)$ with hand $\mathrm{OA}$ and Heberden's nodes who were admitted to the Ankara University Faculty of Medicine, Department of Physical Medicine and Rehabilitation Outpatient Clinic between April 2007 and December 2009, and the control group was comprised of 80 postmenopausal female patients (mean age $57.62 \pm 5.39$ ) without these symptoms. Those with inflammatory joint disease, congenital deformities, endocrinological disease, diseases that affected bone metabolism (or those taking drugs that affected bone metabolism), past hormone replacement therapy, and those over the age of 75 were excluded from the study.

Blood biochemistry, thyroid function tests, and bone turnover markers (serum calcium, phosphorus, alkaline phosphatase, osteocalcin, and urine deoxypyridinoline), and 25-hydroxyvitamin D3 [25(OH)D3] levels were measured in the two groups, and the BMD levels along with the lateral thoracolumbar X-ray and anteroposterior (AP) radiographs of the pelvis, knees, and hands were compared. For each of the groups, the X-rays were taken by the same technician with the same device, and the evaluation of the radiographs was done using the Kellgren-Lawrence (KL) scale with grades of 0 , I, II, III, and IV. Furthermore, the lumbar and femoral BMDs in both groups were measured by the same technician with the same dualenergy X-ray absorptiometry (DXA) using $\mathrm{g} / \mathrm{cm}^{2}$.

\section{Statistical evaluation}

The SPSS for Windows version 11.5 for Windows software program (SPSS Inc., Chicago, IL, USA) was used to analyze the data. In addition, the MannWhitney U test was used to compare two independent groups, and the Kruskal-Wallis analysis of variance (ANOVA) was used to compare more than two groups. Multiple comparison tests were used to determine differences between the groups, and a $p$ value of $<0.05$ was considered to be statistically significant. The results were expressed as median (minimummaximum), and the patients' ages were reported as mean \pm standard deviation. 


\begin{tabular}{|c|c|c|c|c|c|}
\hline \multirow[t]{2}{*}{ Parameter } & \multicolumn{2}{|c|}{ OA group $(n=80)$} & \multicolumn{2}{|c|}{ Control group $(n=80)$} & \multirow[t]{2}{*}{$p$} \\
\hline & Median & Min.-max. & Median & Min.-max. & \\
\hline $25(\mathrm{OH}) \mathrm{D} 3$ & 20.6 & $(6-55)$ & 17.4 & $(4.1-65.8)$ & $0.025(<0.05)$ \\
\hline Median lumbar BMD & 0.838 & $(0.610-1.610)$ & 0.958 & $(0.610-1.510)$ & $0.001(<0.05)$ \\
\hline L1 T score & -1.10 & $(-3.6-+2.5)$ & -1.0 & $(-4.0-+1.7)$ & $0.925(>0.05)$ \\
\hline L2 T score & -1.04 & $(-3.8-+4.1)$ & -1.05 & $(-4.0-+2.1)$ & $0.358(>0.05)$ \\
\hline L3 T score & -1.0 & $(-3.4-+6.3)$ & -1.1 & $(-3.8-+3.7)$ & $0.320(>0.05)$ \\
\hline L4 T score & -1.4 & $(-3.7-+2.1)$ & -1.35 & $(-4.1-+5.0)$ & $0.499(>0.05)$ \\
\hline L1-4 T score & -1.1 & $(-3.6-+3.8)$ & -1.3 & $(-4.0-+3.3)$ & $0.454(>0.05)$ \\
\hline Total femur BMD & 0.865 & $(0.602-1.158)$ & 0.874 & $(0.644-1.490)$ & $0.441(>0.05)$ \\
\hline Femur total $\mathrm{T}$ score & -0.55 & $(-2.8-+1.3)$ & -0.55 & $(-2.4-+2.8)$ & $0.595(>0.05)$ \\
\hline Femur neck BMD & 0.747 & $(0.357-1.072)$ & 0.757 & $(0.464-1.662)$ & $0.165(>0.05)$ \\
\hline Femur neck $\mathrm{T}$ score & -1.0 & $(-3.2-+1.5)$ & -0.9 & $(-2.5-+2.3)$ & $0.119(>0.05)$ \\
\hline
\end{tabular}

\section{RESULTS}

There was no statistically significant difference regarding the age of the patients between the groups ( $>0.05)$. The 25(OH)D3 levels were higher in the OA group compared with the control group, and this difference was statistically significant $(\mathrm{p}<0.05)$. Additionally, the lumbar spine BMD in the control group was significantly higher than in the OA group $(p<0.05)$. The other outcomes revealed no significant differences between the two groups ( $>0.05)$ (Table 1).

Although not symptomatic, radiographic OA was detected in the control group. Therefore, both groups were compared with regard to OA grades, and these were higher in the OA group than the control group and were statistically significant $(\mathrm{p}<0.05)$ (Table 2$)$.

Because OA was detected in the control group, although at low levels, the lumbar spine $t$ score values of both groups were compared according to their degree of $\mathrm{OA}$, and based on the thoracolumbar lateral $\mathrm{X}$-ray degrees, the values were higher in the control group for patients with a KL grade of 0 . Moreover, the difference was statistically significant $(\mathrm{p}<0.05)$.
However, no other statistically significant differences were detected.

In addition, the lumbar spine $\mathrm{T}$ scores according to the AP pelvic radiograph OA grades, the femoral neck $\mathrm{T}$ scores, and the BMD scores were also compared between the groups. With regard to the femoral neck $\mathrm{T}$ scores, in the patients who were $\mathrm{KL}$ grade II, the values of the controls were higher than those with OA, and the result was statistically significant $(\mathrm{p}<0.05)$. However, no relationships were found between patients with other KL grades on the AP pelvic radiographs (Table 3 ).

Furthermore, no statistically significant differences were detected between the two groups regarding their lumbar spine $\mathrm{T}$ score values according to the AP knee radiographs of the patients ( $p>0.05)$, and no statistically significant differences were detected regarding their lumbar spine $\mathrm{T}$ score values according to the AP hand radiographs either ( $p>0.05)$.

For the OA group, the lumbar spine $\mathrm{T}$ score values based on the KL scores of the patients for different regions were also compared. When the lumbar spine $\mathrm{T}$ scores of the thoracolumbar lateral

Table 2. Comparison of osteroarthritis grades between groups

\begin{tabular}{|c|c|c|c|c|c|}
\hline \multirow[t]{2}{*}{ Parameter } & \multicolumn{2}{|c|}{ Grade of OA group $(n=80)$} & \multicolumn{2}{|c|}{ Grade of OA in control group $(n=80)$} & \multirow[b]{2}{*}{$p$} \\
\hline & Median & Min.-max. & Median & Min.-max. & \\
\hline Lateral thoracolumbar X-ray & 2 & $0-3$ & 1 & $0-3$ & $<0.001$ \\
\hline Anteroposterior radiographs of the pelvis & 2 & $1-4$ & 1 & $1-2$ & $<0.001$ \\
\hline Anteroposterior radiographs of the knee & 2 & $1-4$ & 1 & $0-3$ & $<0.001$ \\
\hline Anteroposterior radiographs of the hand & 3 & $2-4$ & 1 & $0-2$ & $<0.001$ \\
\hline
\end{tabular}




\begin{tabular}{|c|c|c|c|c|c|}
\hline \multirow[t]{2}{*}{ Parameter } & \multicolumn{2}{|c|}{ OA group $(n=51)$} & \multicolumn{2}{|c|}{ Control group $(n=10)$} & \multirow[b]{2}{*}{$p$} \\
\hline & Median & Min.-max. & Median & Min.-max. & \\
\hline L1 T score & -1.1 & $(-3.6-+2.5)$ & -1.3 & $(-3.3-0)$ & 0.654 \\
\hline L2 T score & -0.9 & $(-3.8-+4.1)$ & -1.5 & $(-2.8-+0.8)$ & 0.477 \\
\hline L3 T score & -1.0 & $(-3.4-+6.3)$ & -1.55 & $(-2.8-+0.2)$ & 0.279 \\
\hline L4 T score & -1.4 & $(-3.7-+2.1)$ & -1.85 & $(-3.3-+0.5)$ & 0.453 \\
\hline L1-4 T score & -1.1 & $(-3.6-+3.8)$ & -1.45 & $(-2.9-+0.1)$ & 0.402 \\
\hline Femur neck BMD & 0.743 & $(0.357-1.072)$ & 0.842 & $(0.684-1.662)$ & 0.055 \\
\hline Femur neck T score & -1.0 & $(-3.2-+1.5)$ & -0.05 & $(-1.5-+1.9)$ & 0.034 \\
\hline
\end{tabular}

radiographs were compared, the $\mathrm{T}$ score values of L1 were higher as the OA grade increased, and a statistically significant difference was found between KL grades 0 and I and grades II and III. Although the values also increased between grades I and II, I and III, and II and III, the differences were not statistically significant. Furthermore, no other correlations were found between the lumbar spine $\mathrm{T}$ scores. The same comparisons were made for the control group, but no relationship was found between the thoracolumbar lateral radiograph $\mathrm{OA}$ grades and lumbar spine $\mathrm{T}$ scores (Table 4).

A correlation was noted in the OA group between the L1, L3, L4, and L1-L4 T scores when the AP knee radiographs were compared with the BMD values. We determined that as the OA grade increased, there was a corresponding higher $\mathrm{BMD}$ value. However, this relationship deteriorated in KL grade IV. When the values were examined, the relationships between the L1, L3, and L1-4 T scores and grades I-III and II-III in the knee OA patients were statistically significant, and the relationships between L4 T scores and knee OA grades II and III were also statistically significant. However, no similar connections were found between BMD and knee OA grades in the control group (Table 4).

Additionally, no statistically significant differences were detected regarding the lumbar spine $\mathrm{T}$ scores and $\mathrm{OA}$ grades for different regions in the control group (Table 4).

\section{DISCUSSION}

Osteoarthritis and OP are the most common societal diseases. In clinical practice, studies have indicated that these two diseases are negatively correlated with each other; thus, OA is believed to be protective against OP. ${ }^{[3-6,10,11]}$ However, other studies have suggested that these two diseases can be found together in the same individual..$^{[9,12,13]}$

In theory, a negative relationship between $\mathrm{OA}$ and OP means that the risk of OP in OA patients is less than for those without $\mathrm{OA}$ and that less hip fractures will be seen in these individuals.

Osteoarthritis patients are known to have higher bone tissue values than patients with OP, but it is still uncertain whether the OP patients have higher BMD values than individuals without $\mathrm{OA}$. As a result, despite higher than normal BMD levels in patients with OA, no reduction in complications, such as fracture risk brought on by low BMD, has been seen. The risk of vertebral fractures in postmenopausal women with vertebral $O A$ was researched using data from the Os des Femmes de Lyon (OFELY) study, and it was found that despite higher BMD values, there was no decrease in the fracture risk for women with vertebral $\mathrm{OA}$ and that narrowing in the disc space contributed to the increased risk of vertebral fracture. High BMD values are frequently observed in individuals with $\mathrm{OA}$, but whether or not a reduction in fracture risk exists is still unclear. In fact, the data does not support an association between increased BMD and OA, especially when range of joint narrowing is accepted as a determinant for OA. Despite higher BMD levels in individuals with $\mathrm{OA}$, quadriceps muscle strength may be decreased, and stability and balance may be impaired. This may lead to an increase in falling frequency, resulting in severe falls. For this reason, the risk of fracture in patients with OA may not be as low as expected, indicating that applications for prevention of fractures in patients with OA should not be neglected. ${ }^{[7,8,14]}$

Various theories have been developed to explain the relationship between OA and OP. Osteoarthritis 


\begin{tabular}{|c|c|c|c|c|c|c|c|c|c|c|c|c|}
\hline & \multirow{2}{*}{\multicolumn{3}{|c|}{$\frac{\text { Thoracolumbar X-ray (lateral) }}{\text { BMD levels }}$}} & \multirow{2}{*}{\multicolumn{3}{|c|}{$\frac{\text { Pelvic X-ray (AP) }}{\text { BMD levels }}$}} & \multirow{2}{*}{\multicolumn{3}{|c|}{$\frac{\text { Knee X-ray (AP) }}{\text { BMD levels }}$}} & \multirow{2}{*}{\multicolumn{3}{|c|}{$\frac{\text { Hand X-ray (AP) }}{\text { BMD levels }}$}} \\
\hline & & & & & & & & & & & & \\
\hline & Median & Min.-max. & $p$ & Median & Min.-max. & $p$ & Median & Min.-max. & $p$ & Median & Min.-max. & $p$ \\
\hline \multicolumn{13}{|c|}{ L1 T score } \\
\hline 0 & -2.1 & $(-3.3--1.5)$ & 0.023 & & & & & & & & & \\
\hline 1 & -1.15 & $(-2.4-+2.2)$ & & -1.1 & $(-3.3-+2.2)$ & 0.8 & -1.55 & $(-2.4-+0.7)$ & 0.046 & & & \\
\hline 2 & -1.0 & $(-3.6-+2.5)$ & & -1.1 & $(-3.6-+2.5)$ & & -1.4 & $(-3.6-+2.2)$ & & -1.4 & $(-3.6-+2.2)$ & 0.2 \\
\hline 3 & -0.65 & $(-1.7-+1.0)$ & & -0.85 & $(-1.4-0)$ & & -0.65 & $(-2.2-+2.5)$ & & -1.0 & $(-3.3-+2.5)$ & \\
\hline 4 & & & & -0.75 & $(-1.1--0.4)$ & & -1.05 & $(-2.1-+0.1)$ & & -1.1 & $(-2.2--0.1)$ & \\
\hline \multicolumn{13}{|c|}{ L2 T score } \\
\hline 0 & -1.7 & $(-3.8--0.9)$ & 0.13 & & & & & & & & & \\
\hline 1 & -0.94 & $(-3.2-+2.0)$ & & -1.08 & $(-3.4-+2.0)$ & 0.9 & -1.7 & $(-2.2--0.5)$ & 0.06 & & & \\
\hline 2 & -1.2 & $(-3.4-+4.1)$ & & -0.9 & $(-3.8-+4.1)$ & & -1.04 & $(-3.8-+2.0)$ & & -1.4 & $(-3.4-+2.0)$ & 0.15 \\
\hline 3 & -0.8 & $(-2.0-+1.2)$ & & -1.35 & $(-1.9-+1.2)$ & & -0.7 & $(-3.4-+4.1)$ & & -0.9 & $(-3.8-+4.1)$ & \\
\hline 4 & & & & -1.35 & $(-1.4--1.3)$ & & -1.0 & $(-2.9-+1.5)$ & & -0.8 & $(-2.9-+0.9)$ & \\
\hline \multicolumn{13}{|c|}{ L3 T score } \\
\hline 0 & -1.5 & $(-3.4--1.0)$ & 0.28 & & & & & & & & & \\
\hline 1 & -0.94 & $(-3.2-+2.0)$ & & -1.0 & $(-2.5-+2.13)$ & 0.9 & -1.8 & $(-2.4-+0.3)$ & 0.013 & & & \\
\hline 2 & -0.9 & $(-3.1-+6.3)$ & & -1.0 & $(-3.4-+6.3)$ & & -1.3 & $(-3.4-+2.13)$ & & -1.055 & $(-2.7-+1.2)$ & 0.03 \\
\hline 3 & -0.65 & $(-2.1-+2.3)$ & & -0.85 & $(-2.1-+2.3)$ & & -0.25 & $(-3.1-+6.3)$ & & -0.6 & $(-3.4-+6.3)$ & \\
\hline 4 & & & & -1.0 & $(-1.5--0.5)$ & & -0.85 & $(-2.7-+0.7)$ & & -1.0 & $(-2.7-+0.8)$ & \\
\hline \multicolumn{13}{|c|}{ L4 T score } \\
\hline 0 & -1.6 & $(-3.7--0.8)$ & 0.06 & & & & & & & & & \\
\hline 1 & -1.9 & $(-3.7-+2.1)$ & & -1.7 & $(-2.7-+1.1)$ & 0.5 & -1.75 & $(-2.2-+1.6)$ & 0.019 & & & \\
\hline 2 & -1.4 & $(-3.1-+2.0)$ & & -1.4 & $(-3.7-+2.1)$ & & -1.9 & $(-3.7-+2.1)$ & & -1.9 & $(-2.7-+2.1)$ & 0.41 \\
\hline 3 & -0.4 & $(-2.6-+2.1)$ & & -0.65 & $(-1.9-+1.2)$ & & -0.45 & $(-2.8-+2.1)$ & & -1.2 & $(-3.7-+2.1)$ & \\
\hline 4 & & & & -0.8 & $(-1.3--0.3)$ & & -0.75 & $(-3.7-+0.8)$ & & -0.7 & $(-3.7-0)$ & \\
\hline \multicolumn{13}{|c|}{ L1-4 } \\
\hline 0 & -1.6 & $(-3.6--1.1)$ & 0.08 & & & & & & & & & \\
\hline \multicolumn{13}{|c|}{ T score } \\
\hline 1 & -1.2 & $(-2.9-+1.6)$ & & -1.1 & $(-2.2-+1.6)$ & 0.9 & -1.7 & $(-2.1-+0.6)$ & 0.015 & & & \\
\hline 2 & -1.1 & $(-2.9-+3.8)$ & & -1.1 & $(-3.6-+3.8)$ & & -1.25 & $(-3.6-+1.6)$ & & -1.45 & $(-2.7-+1.6)$ & 0.27 \\
\hline 3 & -0.85 & $(-2.1-+2.1)$ & & -0.9 & $(-1.5-+1.1)$ & & -0.65 & $(-2.9-+3.8)$ & & -1.0 & $(-3.6-+3.8)$ & \\
\hline 4 & & & & -0.95 & $(-1.3--0.6)$ & & -0.9 & $(-2.9-+0.6)$ & & -0.9 & $(-2.9-+0.3)$ & \\
\hline
\end{tabular}

is primarily a disease of the subchondral bone, and a hard bone with high BMD may increase the mechanical stress over the cartilage. On the other hand, it has been suggested that osteoporotic bone absorbs the loads more effectively than normal bone. Thus, less stress is transferred to the underlying cartilage ${ }^{[15]}$ Radin and Rose ${ }^{[16]}$ postulated that the loss of subchondral bone elasticity or failure may cause $\mathrm{OA}$, and this idea was widely accepted. According to this view, the loss of elasticity of the subchondral bone impairs the ability to absorb shock, which leads to the easier compression of articular cartilage and causes nutritional deterioration. Subsequently, the nutrition disorders then generate compression necrosis and secondary cartilage damage. Osteoarthritis develops after healed microfractures. Osteoporotic bone is more elastic, and this elasticity protects the articular cartilage against OA. Gevers et al. ${ }^{[17]}$ lent support to the view of Radin and Rose $\mathrm{e}^{[16]}$ by claiming that the primary disorder in OA does not involve the articular cartilage but the subchondral bone. They also stated that primary OA is part of a general bone disease. According to Pogrund et al ${ }^{[18]}$ the hypothesis in the Radin and Rose ${ }^{[16]}$ study is contrary to the facts related to OP because the number of trabeculae is reduced in $\mathrm{OP}$, and the remaining trabeculae get thinner. This situation is not conducive to elasticity and support of the subchondral bone. Todd et al. ${ }^{[19]}$ showed that isolated trabecular fractures occur as a result of fatigue in the osteoporotic proximal femur and that this contributes to major fractures. Microfractures in the femoral head cause local collapse and result in incompatibility in cartilage, leading to OA.

The relationship between OA and OP varies between primary generalized $\mathrm{OA}$ and localized $\mathrm{OA}$. The coexistence of $\mathrm{OA}$ and $\mathrm{OP}$ in the hand 
joints has been previously shown. ${ }^{[9,19,20]}$ Schneider et al. ${ }^{[21]}$ determined that female patients with clinically diagnosed hand OA had significantly lower femoral BMD, and Sowers et al. ${ }^{[22]}$ found that after a 23 -year follow-up, the initial bone mass was higher in female patients who subsequently developed hand OA than those who did not. However, over time, a greater loss of bone was observed in these patients.

Hand OA with Heberden's nodes is defined as a type of primary generalized OA. In our study, in order to investigate the relationship between primary generalized $\mathrm{OA}$ and $\mathrm{OP}$, postmenopausal female patients with hand OA associated with Heberden's nodes were included. When we examined the results of our study, the 25(OH)D3 value in the OA group was higher than in the control group, and the difference was statistically significant. In addition, the $25(\mathrm{OH}) \mathrm{D} 3$ levels were statistically significantly lower in the control group, but the lumbar BMD values were statistically significantly higher than those in the OA group. These results led us to wonder whether or not the high presence of vitamin $\mathrm{D}$ is protective in terms of high BMD. With normal BMD values, the serum vitamin $D$ levels in women with hip OA have been shown to be low. However, our results indicate that even for women with advanced OA, OP and vitamin $\mathrm{D}$ deficiency should be considered. On the other hand, we found no significant differences between the lumbar spine, femoral neck, and femur total $\mathrm{T}$ scores and the total femur and femoral neck $\mathrm{BMD}$ values in the $\mathrm{OA}$ and control groups.

Hordon et al. ${ }^{[23]}$ compared the hip, spine, and total body BMDs of 20 postmenopausal women with primary generalized $\mathrm{OA}$ and 89 control subjects and found higher spine and total body BMD values in the OA group. However, they failed to find a significant increase in hip BMD values. In contrast, Reid et al. ${ }^{[24]}$ and Price et al. ${ }^{[25]}$ found no differences in the BMD values between the primary generalized OA patients and the controls.

Dequeker et al. ${ }^{[26]}$ ascertained that a high BMD in generalized OA patients was related to low bone turnover. They also showed there was low bone turnover when using d-pyridinoline cross-chains as a bone resorption marker. In addition, they found that there were high concentrations of insulin-like growth factor (IGF) I-II and transforming growth factor beta (TGF- $\beta$ ) in the region of OA.

Although we did not intend to have OA patients in the control group, radiographic OA (spine, knee, etc.) was detected in some asymptomatic patients. Therefore, both groups were compared regarding OA grades. When these were examined, the degree of OA was higher in the OA group than in the controls and was statistically significant $(\mathrm{p}<0.001)$ (Table 2$)$. Since low degrees of OA were detected in the control group, the lumbar spine $\mathrm{T}$-score values were also compared in both groups according to the degree of OA.

When the lumbar vertebral $\mathrm{T}$ scores were compared in the patients with the 0 degree thorocolumbar lateral radiograph $\mathrm{KL}$ scores, the $\mathrm{L} 1$ and $\mathrm{L} 3 \mathrm{~T}$ scores were higher in the control than the OA group. However, when the lateral thoracolumbar radiographs of patients with OA grades I and II were compared, the $\mathrm{T}$ scores of the lumbar spine in the OA group were higher than in the control group, but no statistically significant differences were observed. Five patients had grade $0 \mathrm{OA}$ on lateral thoracolumbar radiographs in the OA group, and nine subjects in the control group had the same grade; however, the relevance of these results is not clear.

When we compared the lumbar spine $\mathrm{T}$ scores of OA patients based on OA grades identified via the thoracolumbar lateral radiographs, the $\mathrm{T}$ scores of L1 were higher and increased according to the degree of OA. When we examined these values, a statistically significant difference was found between OA grade 0 and grades I, II, and III. When grades I and II, I and III, and II and III were compared, even though the values increased as the OA got worse, there were no statistically significant differences. When the L4 $\mathrm{T}$ scores of grade $0 \mathrm{OA}$ patients and grade III OA patients were compared, there was a $p$ value of 0.067 . Though this value was not statistically significant, it did approach that level. No other similar correlations were found between the lumbar spine $\mathrm{T}$ scores (Table 4). For the control group, a comparison was made in the same way, but there was no relationship between the thoracolumbar lateral radiograph OA grades and lumbar spine $\mathrm{T}$ scores.

Dai ${ }^{[27]}$ explored the relationship between OA and OP in the lumbar spine of 252 elderly subjects and compared patients with spinal OA to patients with osteoporotic fractures and detected that individuals with OP do not develop OA in the lumbar spine. In addition, higher BMD values were found in those with spinal OA. The author concluded that OA slows down the growth of OP and that OP protects against OA. 
In postmenopausal women, the severity of disc narrowing was associated with a generalized increase in BMD and a decrease in the rate of bone resorption, but this was not true for the presence of osteophytes. These results are consistent with the hypothesis that OA through disc space narrowing has a protective effect against bone loss that is mediated by a lower rate of bone resorption. However, BMD in the spine is not a relevant surrogate marker for the assessment of OP in the spine in patients with OA, and the debate continues regarding the relationship between $\mathrm{OA}$ and $\mathrm{OP}$ because of the contradictory data in the literature. ${ }^{[28]}$

In our study, when the AP pelvic radiographs in patients with OA grade II were compared with the femoral neck $\mathrm{T}$ scores, the control group had higher values than the OA group, and a statistically significant difference was found. In this evaluation, 70 patients from the OA group and 21 patients from the control group were compared. Furthermore, the femoral neck $\mathrm{T}$ values of patients with generalized OA were lower than for patients with hip OA in the control group $(\mathrm{p}=0.055)$. This result indicated a positive relationship between coxarthrosis and OP, which was contrary to what we expected (Table 3).

For both groups, the lumbar spine $\mathrm{T}$ scores based on the OA grades as determined by AP pelvic radiographs along with the femoral neck BMD and femoral neck $\mathrm{T}$ scores were compared, but no significant correlations were detected.

The negative correlation between primary OA and OP was noticed for the first time in the clinic by Foss and Byers. ${ }^{[29]}$ They diagnosed OA in only three of 140 patients with osteoporotic hip fractures and reported that hip fractures and primary hip OA are rarely found together. This led to the idea that OA patients have a high BMD throughout the skeletal system or at least locally in regions adjacent to the OA joint.

The results of studies related to primary hip OA do not comply with one another. For example, in the study by Savas, ${ }^{[30]}$ the hip and spine BMD values of patients with hip OA did not differ significantly when compared with the controls. However, when the mean values were examined one by one, the BMD values and $\mathrm{T}$ and $\mathrm{Z}$ scores of the patients with hip OA were higher than the controls. The author also found that the higher the OA grade in hip OA patients, the more the femoral neck BMD values increased, but with grade IV OA patients, this relationship was disrupted.
Furthermore, it is known that the loss of trabecular bone structure due to this disruption can occur in this stage. Foss and Byers ${ }^{[29]}$ detected BMD values higher than the norm using the same method as Savas, but Solomon et al. ${ }^{[13]}$ found no increase in BMD of the second metacarpal bone in 105 female and male patients with primary hip OA. Carlsson et al. ${ }^{[31]}$ measured BMD using single-photon absorptiometry from the forearms of hip OA patients and a control group. When a proximal region containing mainly cortical bone was selected, no significant difference was observed between the patients and controls, but when a distal region containing primarily trabecular bone was selected, the BMD values were significantly higher in the OA group. Pogrund et al. ${ }^{[1]}$ evaluated the pelvic radiographs of 641 patients in terms of OP and OA using their own method, and only $0.5 \%$ had a combination of OA and OP. Cooper et al. ${ }^{[3]}$ evaluated the radiographs of 314 male and female patients over the age of 50 in terms of hip OA according to the KL scale. These patients had been admitted to the hospital for reasons unrelated to the skeletal system. The BMD was evaluated by the method employed by Singh, and a significant negative relationship was found between BMD and OA. ${ }^{[3]}$ However, due to the low validity of the Singh grading in this study, the results were controversial. In addition, Knight et al. ${ }^{[32]}$ measured the femoral BMD of 50 primary hip OA patients with DXA and found high BMD values at the femoral neck and Ward's triangle.

The electron microscopic examination of femur heads of patients undergoing surgery either for hip fracture or coxarthrosis was studied by Shen et al., ${ }^{[33]}$ and they found significant differences in the trabecular bone, collagen fibers, lacunae, and osteoblasts between postmenopausal women with $\mathrm{OP}$ and OA. These findings support the hypothesis that there is an inverse relationship between $\mathrm{OP}$ and OA. ${ }^{[33]}$

In our study, we found no statistically significant difference between the $\mathrm{OA}$ and control groups regarding the lumbar vertebral $\mathrm{T}$ scores as determined by the AP knee radiographs ( $\mathrm{p}>0.05)$.

For the OA group, correlations were found between the L1, L3, L4, and L1-L4 T scores when the AP knee radiographs and BMD values were compared. When these values were examined, the relationship between the L1, L3 and L1-L4 T scores and knee OA grades I-III and grades II-III in knee OA patients was statistically significant. Furthermore, the 
correlation between the L4 T score values and knee OA grades II and III was statistically significant. When we compared the results of the L2 T score with knee OA grades I and III, the $p$ value was 0.065 . Since there was a relationship between the $\mathrm{T}$ scores of the other lumbar areas and knee OA, this value was accepted as having statistical significance. The same comparison was also done for the control group, but no relationship was found between the BMD and degrees of knee OA (Table 4).

In the study by Durlanik et al., ${ }^{[34]}$ the proximal femur, lumbar spine and distal radius BMDs were examined in 220 patients with knee OA, and the lumbar and femoral BMD values were higher in those with grade I and II knee OA. These values were statistically significant $(\mathrm{p}<0.05)$. The BMD in patients with grade III and IV OA were higher than in the controls, but it was statistically insignificant. In addition, no statistically significant relationship was identified between the distal radius $\mathrm{BMD}$ and knee $\mathrm{OA}$.

As reported by Arden et al. ${ }^{[35]}$ and Hart et al., ${ }^{[36]}$ the Chingford study detected high lumbar spine and hip BMD values in the knee OA group and found that OA had no protective effect on hip fractures. The authors believe that this was because these patients were less skilled, prone to falling, and unable to protect themselves when they fell.

Hannan et al. ${ }^{[37]}$ examined the Framingham study in which women over 63 years of age were examined, and hip BMD values were higher in patients who were suspected of having or definitely had radiographic changes related to knee OA. ${ }^{[37]}$

In a recent study by Abdin-Mohamed et al., ${ }^{[38]}$ radiographic $\mathrm{OA}$ was found to be related to a significant increase in bone area and strength, indicating that the association between radiographic $\mathrm{OA}$ and areal BMD is mediated through bone size rather than volumetric BMD. However, radiographic OA was not associated with an increase in volumetric $\mathrm{BMD}$ as determined by peripheral quantitative computed tomography (CT).

In our study, the AP hand radiographs used to determine the OA grades of the study participants and the BMD values were compared in the OA group. As the hand OA increased in grades II and III, the L3 $\mathrm{T}$ score also increased, and the result was statistically significant. However, this finding could be open to argument because there was no such relationship in the other lumbar areas (Table 4).
In addition, Bağış et al. ${ }^{[39]}$ did not detect a correlation between hand $\mathrm{OA}$ grades and $\mathrm{BMD}$, leading them to determine that $\mathrm{OA}$ and $\mathrm{OP}$ are different clinical entities.

Our research had several limitations. Although some of the patients in the control group did not have OA symptoms, low-grade OA was detected in different regions. Therefore, the numbers of patients in the OA group and the control group were just enough for a comparison. In addition, due to the small number of patient subgroups, the results of our comparisons are open to debate.

\section{Conclusion}

Through our research, we were able to determine that primary generalized $\mathrm{OA}$ is not protective against OP. In the patients with undeveloped OA, the lumbar spine BMD values were lower in the generalized OA group than the control group. However, the BMD values became higher as the OA grades increased in the thoracolumbar region in the primary generalized OA group. This result may be misleading due to the presence of osteophytes because BMD of the lumbar region was measured in the AP position via DXA. In addition, the femoral neck BMD values were lower for the hip OA patients in the group of primary generalized OA patients than for those with primary coxarthrosis. This suggests that primary coxarthrosis may be protective against OP. Therefore, our data provided no definitive answer to the question of whether knee OA is protective against OP.

Despite numerous studies on this subject, there are conflicting results. These contradictions suggest that there is a very complicated relationship between these two diseases. Both have a multifactorial etiology, which might explain the varying research conclusions. In fact, genetic, metabolic, mechanical, and endocrine factors show both differences and similarities between OA and OP. ${ }^{[40]}$ Although we had some encouraging results, none of them provided conclusive evidence regarding the relationship between these two diseases. To clarify this issue, further studies with larger patient groups are needed, and separate information should be included for each joint and there should also be a long-term follow-up period.

\section{Declaration of conflicting interests}

The authors declared no conflicts of interest with respect to the authorship and/or publication of this article. 


\section{Funding}

The authors received no financial support for the research and/or authorship of this article.

\section{REFERENCES}

1. Kutsal YG, Kara M. Diz osteoartriti. In: Sarıdoğan M, editör. Tanıdan tedaviye osteoartrit. İstanbul: Nobel Tip Kitabevi; 2007. s. 149-61.

2. Grainger R, Cicuttini FM. Medical management of osteoarthritis of the knee and hip joints. Med J Aust 2004;180:232-6.

3. Cooper C, Cook PL, Osmond C, Fisher L, Cawley MI. Osteoarthritis of the hip and osteoporosis of the proximal femur. Ann Rheum Dis 1991;50:540-2.

4. Sowers M, Lachance L, Jamadar D, Hochberg MC, Hollis $\mathrm{B}$, Crutchfield $\mathrm{M}$, et al. The associations of bone mineral density and bone turnover markers with osteoarthritis of the hand and knee in pre- and perimenopausal women. Arthritis Rheum 1999;42:483-9.

5. Burger $H$, van Daele $P L$, Odding E, Valkenburg HA, Hofman A, Grobbee DE, et al. Association of radiographically evident osteoarthritis with higher bone mineral density and increased bone loss with age. The Rotterdam Study. Arthritis Rheum 1996;39:81-6.

6. Zhang Y, Hannan MT, Chaisson CE, McAlindon TE, Evans SR, Aliabadi P, et al. Bone mineral density and risk of incident and progressive radiographic knee osteoarthritis in women: the Framingham Study. J Rheumatol 2000;27:1032-7.

7. Arden NK, Nevitt MC, Lane NE, Gore LR, Hochberg MC, Scott JC, et al. Osteoarthritis and risk of falls, rates of bone loss, and osteoporotic fractures. Study of Osteoporotic Fractures Research Group. Arthritis Rheum 1999;42:1378-85.

8. Sornay-Rendu E, Munoz F, Duboeuf F, Delmas PD; OFELY Study. Disc space narrowing is associated with an increased vertebral fracture risk in postmenopausal women: the OFELY Study. J Bone Miner Res 2004;19:1994-9.

9. Yalçın P. Osteoartrit osteoporoz ilişkisi. In: Sarıdoğan M, editör. Tanıdan tedaviye osteoartrit. İstanbul: Nobel Tip Kitabevi; 2007. s. 111-15.

10. Weintroub S, Papo J, Ashkenazi M, Tardiman R, Weissman SL, Salama R. Osteoarthritis of the hip and fracture of the proximal end of the femur. Acta Orthop Scand 1982;53:261-4.

11. Pogrund H, Rutenberg M, Makin M, Robin G, Menczel J, Steinberg R. Osteoarthritis of the hip joint and osteoporosis: a radiological study in a random population sample in Jerusalem. Clin Orthop Relat Res 1982;164:130-5.

12. Dequeker J. The relationship between osteoporosis and osteoarthritis. Clin Rheum Dis 1985;11:271-96.

13. Solomon L, Schnitzler CM, Browett JP. Osteoarthritis of the hip: the patient behind the disease. Ann Rheum Dis 1982;41:118-25.
14. Sornay-Rendu E, Munoz F, Duboeuf F, Delmas PD; OFELY Study. Disc space narrowing is associated with an increased vertebral fracture risk in postmenopausal women: the OFELY Study. J Bone Miner Res 2004;19:1994-9.

15. Buckland-Wright C. Subchondral bone changes in hand and knee osteoarthritis detected by radiography. Osteoarthritis Cartilage 2004;12 Suppl A:S10-9.

16. Radin EL, Rose RM. Role of subchondral bone in the initiation and progression of cartilage damage. Clin Orthop Relat Res 1986;213:34-40.

17. Gevers G, Dequeker J, Martens M, Van Audekercke R, Nyssen-Behets C, Dhem A. Biomechanical characteristics of iliac crest bone in elderly women according to osteoarthritis grade at the hand joints. J Rheumatol 1989;16:660-3.

18. Pogrund H, Rutenberg M, Makin M, Robin G, Menczel J, Steinberg R. Osteoarthritis of the hip joint and osteoporosis: a radiological study in a random population sample in Jerusalem. Clin Orthop Relat Res 1982;164:130-5.

19. Todd RC, Freeman MA, Pirie CJ. Isolated trabecular fatigue fractures in the femoral head. J Bone Joint Surg [Br] 1972;54:723-8.

20. Hochberg MC, Lethbridge-Cejku M, Tobin JD. Bone mineral density and osteoarthritis: data from the Baltimore Longitudinal Study of Aging. Osteoarthritis Cartilage 2004;12 Suppl A:S45-8.

21. Schneider DL, Barrett-Connor E, Morton DJ, Weisman M. Bone mineral density and clinical hand osteoarthritis in elderly men and women: the Rancho Bernardo study. J Rheumatol 2002;29:1467-72.

22. Sowers M, Zobel D, Weissfeld L, Hawthorne VM, Carman W. Progression of osteoarthritis of the hand and metacarpal bone loss. A twenty-year followup of incident cases. Arthritis Rheum 1991;34:36-42.

23. Hordon LD, Stewart SP, Troughton PR, Wright V, Horsman A, Smith MA. Primary generalized osteoarthritis and bone mass. Br J Rheumatol 1993;32:1059-61.

24. Reid DM, Kennedy NS, Smith MA, Tothill P, Nuki G. Bone mass in nodal primary generalised osteoarthrosis. Ann Rheum Dis 1984;43:240-2.

25. Price T, Hesp R, Mitchell R. Bone density in generalized osteoarthritis. J Rheumatol 1987;14:560-2.

26. Dequeker J, Mohan S, Finkelman RD, Aerssens J, Baylink DJ. Generalized osteoarthritis associated with increased insulin-like growth factor types I and II and transforming growth factor beta in cortical bone from the iliac crest. Possible mechanism of increased bone density and protection against osteoporosis. Arthritis Rheum 1993;36:1702-8.

27. Dai LY. The relationship between osteoarthritis and osteoporosis in the spine. Clin Rheumatol 1998; 17:44-6.

28. Ichchou L, Allali F, Rostom S, Bennani L, Hmamouchi I, Abourazzak FZ, et al. Relationship between spine osteoarthritis, bone mineral density and bone turn over markers in post menopausal women. BMC Womens Health 2010;10:25. 
29. Foss MV, Byers PD. Bone density, osteoarthrosis of the hip, and fracture of the upper end of the femur. Ann Rheum Dis 1972;31:259-64.

30. Savaş S. Primer kalça OA'li hastaların kalça ve omurga kemik mineral dansitelerinin değerlendirilmesi [Uzmanlık Tezi] Ankara Üniversitesi Tıp Fakültesi Fizik Tedavi ve Rehabilitasyon Anabilim Dalı, Ankara; 1996.

31. Carlsson A, Nilsson BE, Westlin NE. Bone mass in primary coxarthrosis. Acta Orthop Scand 1979;50:187-9.

32. Knight SM, Ring EF, Bhalla AK. Bone mineral density and osteoarthritis. Ann Rheum Dis 1992;51:1025-6.

33. Shen Y,Zhang ZM, Jiang SD, Jiang LS, DaiLY. Postmenopausal women with osteoarthritis and osteoporosis show different ultrastructural characteristics of trabecular bone of the femoral head. BMC Musculoskelet Disord 2009;10:35.

34. Durlanık G, Şahin F, Merdol F, Yılmaz F, Kuran B. Diz osteoartritinin lomber omurga, proksimal femur ve distal radius kemik mineral yoğunluğu ile ilişkisi. Osteoporoz Dünyasından 2003;9:12-5.

35. Arden NK, Griffiths GO, Hart DJ, Doyle DV, Spector TD. The association between osteoarthritis and osteoporotic fracture: the Chingford Study. Br J Rheumatol 1996;35:1299-304.
36. Hart DJ, Mootoosamy I, Doyle DV, Spector TD. The relationship between osteoarthritis and osteoporosis in the general population: the Chingford Study. Ann Rheum Dis 1994;53:158-62.

37. Hannan MT, Anderson JJ, Zhang Y, Levy D, Felson DT. Bone mineral density and knee osteoarthritis in elderly men and women. The Framingham Study. Arthritis Rheum 1993;36:1671-80.

38. Abdin-Mohamed M, Jameson K, Dennison EM, Cooper C, Arden NK; Hertfordshire Cohort Study Group. Volumetric bone mineral density of the tibia is not increased in subjects with radiographic knee osteoarthritis. Osteoarthritis Cartilage 2009; 17:174-7.

39. Bağış S, Şahin G, Özışık S, Yıldız A, Kanık A, Erdoğan C. The relationship between hand osteoarthritis and osteoporosis in postmenopausal women. T Klin J PM\&R 2003;3:1-5.

40. Tuncer T, The relationship between osteoarthritis and osteoporosis. Review Article. Turkish Journal of Geriatrics. Supplement 2011;4:69-71. 